\title{
РЕЉЕФНИ ПЕЧАТИ НА ДНУ СТАКЛЕНИХ КВАДРАТНИХ БОЦА У НАРОДНОМ МУЗЕЈУ У ПОЖАРЕВЦУ
}

\author{
Антонија С. Ропкић Ђорђевић \\ Београд
}

\author{
e-mail: antonijaropkic@yahoo.com $\mid$ Прегледни рад \\ Примљено: 7. 5. 2021. УДК: 904:736.3(37) 904:666.171(398) \\ Прихваћено: 9. 6.2021. 069.5:94(497.11)
}

\begin{abstract}
Апстракт: У овом раду представљени су рељефни печати на дну стаклених квадратних боца из виминацијумске и античко-византијске збирке Народног музеја у Пожаревиу. Обрађено је девет примерака, од којих један представља случајни налаз са локалитета Чаир, а осам је нађено на јужним некрополама Виминацијума током заштитних археолошких истраживања вршених у другој половини 20. века. ${ }^{1}$ На основу аналогија и покретног материјала, оквирно су датовани у период од друге половине 1. до 3. века. Присуство боча квадратног реципијента у Виминаиијуму указује на развијене трговачке везе са италским и галским областима и отвара могућност импорта стаклених посуда из радионица у Панонији и Далмацији.
\end{abstract}

Кључне речи: Народни музеј Пожаревац, Виминацијум, некропола Више гробаља, некропола Пећине, некропола Велика капија, Чаир, квадратне боче, печати

\section{Увод}

У виминацијумској и античко-византијској збирци Народног музеја у Пожаревцу налази се девет фрагментованих дна са рељефним печатом. Један је забележен као случајни налаз са локалитета Чаир (Кат. 8, Т. II. 3), а осам је нађено током заштитних археолошких ископавања јужних некропола Виминацијума (Више гробаља, Пећине и Велика капија), вршених у периоду од 1979. до 1984. године. Примерак откривен на некрополи Велика капија (Ц-290, Кат. 1, Т. І. 1, сл. 1. 1) налазио се у слоју рушевинског шута објекта. Са некрополе Више гробаља потичу три примерка, од којих су два нађена на жртвеној површини (Ц-3738, Кат. 2, Т. І. 2, сл. 1. 2; Ц-5082, Кат. 3,

\footnotetext{
1 Заштитна археолошка ископавања на античким некрополама Пећине, Више гробаља и Велика капија спровели су Републички завод за заштиту споменика културе, Археолошки Институт САНУ и Народни музеј у Пожаревцу. Пратећа теренска и техничка документација коришћена у овом раду налази се у Одељењу за истраживање, заштиту и документацију Републичког завода за заштиту споменика културе у Београду. Срдачно захваљујем колегиници Драгани Спасић-Ђурић, музејском саветнику Народног музеја у Пожаревцу на уступљеном материјалу.
} 

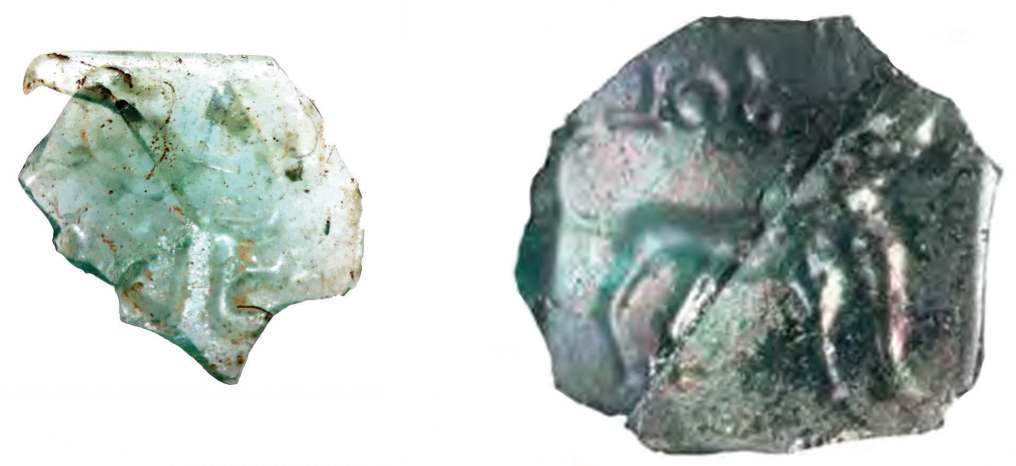

1.

2.

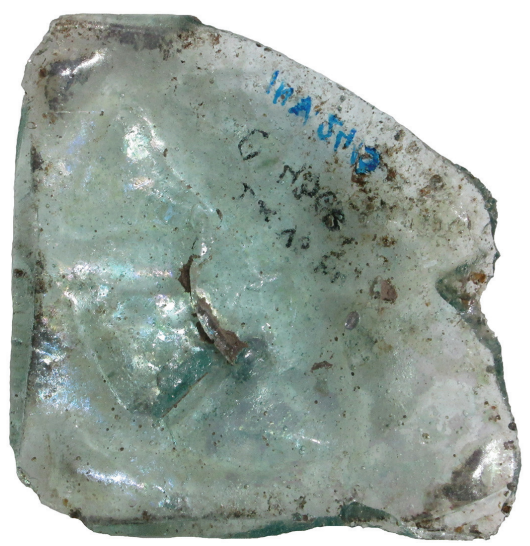

3.

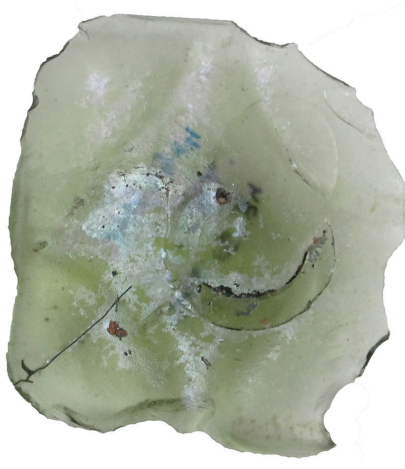

4.

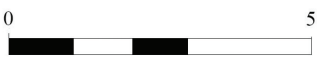

Сл. 1. 1. Локалитет Велика капија, 2-4. Локалитет Више гробаља

Fig. 1. 1. The site of Velika Kapija, 2-4. The site of Više Grobalja 


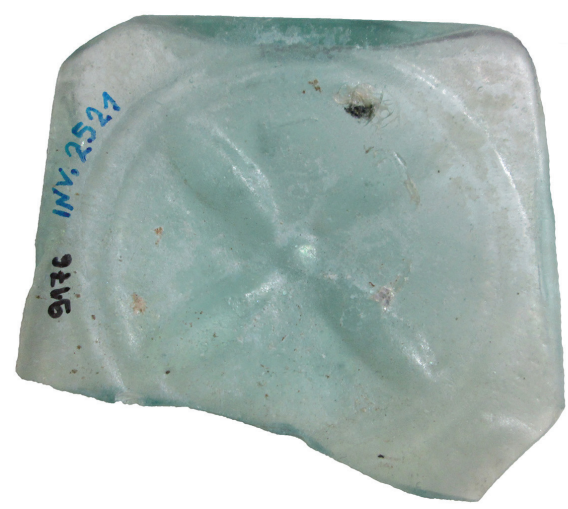

1.

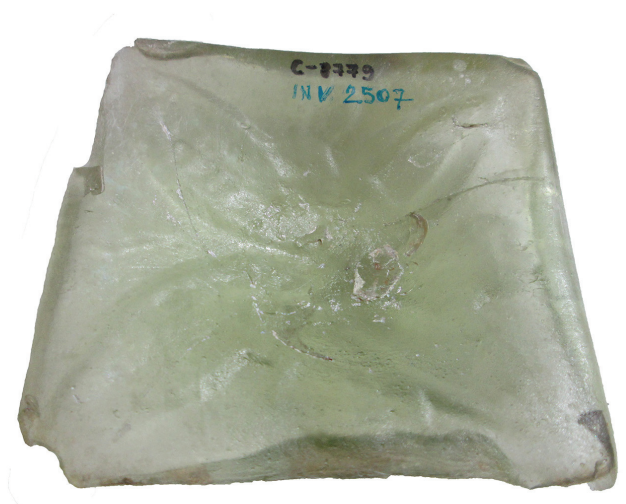

2.

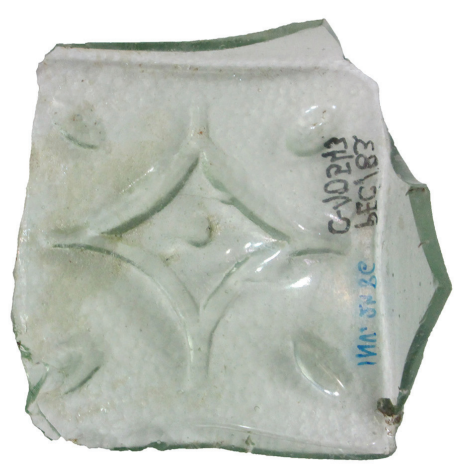

3.

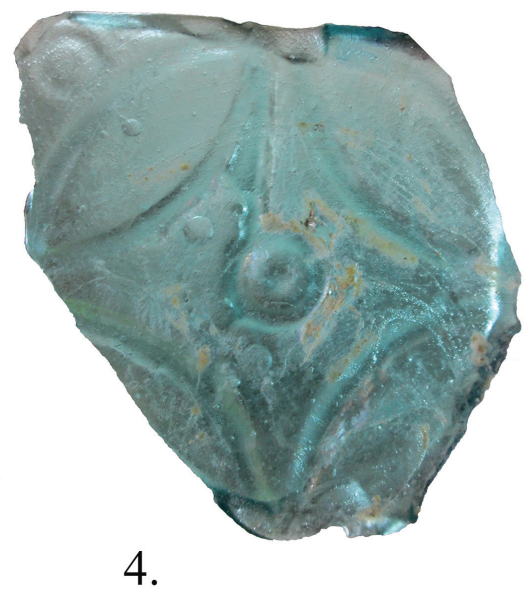

0

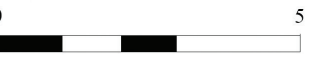

Сл. 2. 1-4. Локалитет Пећине

Fig. 2. 1-4. The site of Pećine 
Т. І. 3, сл. 1. 3), а један изнад нивоа укопавања гробова (Ц-4368, Кат. 4, Т. І. 4, сл. 1. 4). Са некрополе Пећине потичу четири примерка: један је нађен у гробу (Ц-10543, Кат. 5, Т. І. 5, сл. 2. 3), два на жртвеној површини (Ц-8779, Кат. 7, Т. ІІ.2; сл. 2.2; Ц-9176, Кат. 6, Т. ІІ.1; сл. 2.1), а један је откривен у слоју изнад нивоа укопавања гробова (Ц-10659, Кат. 9, Т. ІІ.4; сл. 2.4).

Дна боца из поменутих збирки украшена су са четири типа печата: варијанте ромба, розета, антропоморфном представом са натписом и натписом у два реда.

\section{Типови рељефних печата}

У виминацијумској збирци налази се једно дно Ц-290 са делимично очуваним натписом. Нађен је на локалитету Велика капија 2 . Натпис је постављен у два реда. У горњем реду налазе се три латинична слова од којих треће није читљиво СА(I), у другом реду су видљива два латинична слова (N) Е. (Кат. 1, Т. І. 1, сл. 1. 1). Најсличнији примерци виминацијумском су дна са натписима у три реда нађена на југу Француске, у Шпанији и Италији (Foy 2015, 357, fig. 4. 18, 19).

Једини примерак са зооморфним мотивом и натписом потиче са некрополе Више гробаља, из жртвене површине. ${ }^{3}$ На дну боце Ц-3738 налази се рељефна представа четвороножне животиње (пас?), са делом натписа SOL, постављеним изнад леђа животиње (Кат. 2, T. I. 2, сл. 1. 2). Нису познати компаративни примерци, али су зооморфне представе: птице, коњи, магарци, лисице, веверице, дивље свиње, делфини и рибе констатоване на посудама у медитеранском делу Француске, на Пиринејском полуострву и у Италији. Ти мотиви су често комбиновани са иницијалима произвођача (Foy 2015, 355, fig. 3. 1-4; 12-14; Cabart, Foy, Nenna 2006, F-CAR 157-159, F-CAR 171-173; Fadić, Štefanac, 2012, 18, kat. br. 195).

Рељефни печати са геометријским мотивом нађени су широм Царства (Foy 2015, 355). Мотиви су разнолики: концентрични кругови, мањи кругови у угловима, тачкаста испупчења, разнолико представљени ромбови, мотиви мреже, варијанте крста и свастике, као и комбинације ових мотива (Cabart, Foy, Nenna 2006, 56, Pl. 4-13; Fadić, Štefanac 2012). Геометријски мотив је најзаступљенији на дну виминацијумских квадратних боца. Јавља

\footnotetext{
2 Дно је нађено у слоју шута који је припадао већој грађевини. На основу налаза новца из периода Севера (193-235), покретни материјал је датован у прву половину 3. века (Jordović 1980, 124-126).

3 Жртвени слој изнад кулине датован је на основу разноврсног покретног материјала у период од друге половине 2. до средине 3. века (Zotović, Jordović 1990, 23; Vojvoda, Mrđić 2015).
} 
се у виду ромбова лучно изведених ивица у комбинацији са круговима или елипсоидним орнаментом. Једноставно изведен ромб лучних ивица, оивичен кружићима на угловима, налази се на фрагменту дна боце Ц-5082, откривеној на некрополи Више гробаља, на жртвеној површини. ${ }^{4}$ На дну се налази и полумесечасти траг металног држача (Кат. 4, Т. I. 4, сл. 1. 4). Компаративни примерак евидентиран је на некрополи у Бакру (Volcera) (Fadić, Štefanac 2012, kat. 139, T. XXIV; Ljubić 1882, 51, е. 18)5 , а слично изведен орнамент налази се на боцама нађеним на јужној некрополи у Паризу (Cabart, Foy, Nenna 2006, 93, Pl. 12, F-CAR O9O), непознатом налазишту у Панонији (Barkóczi 1988, 175, Taf. XXXVIII, 410), у Аквилеји (Calvi 1968, Tav. e. 1). Сви примерци су датованим у период од средине 1. до средине 2. века. Рељефни печат у виду ромба лучних ивица, оивиченог елипсоидним орнаментима на угловима, са кружићем у централном делу, Ц-10543 (Кат. 5, Т. I. 5, сл. 2. 3) откривен је на некрополи Пећине, у гробу Г-3485. Компаративни примерци откривени су на локалитетима у Панонији, Далмацији и Хистрији. Са непознатог налазишта у Панонији потиче један примерак датован је у другу половину 1. века (Barkozci 1988, 173, taf. XXXVII, 406). Други панонски примерак евидентиран је на некрополи у Птују (Lazar 2003, Fig. 45.10). У Пули је откривено дно са слично изведеним ромбом уписаним у круг, датовано у период од краја 1. до 3. века (Arheološki muzej Istre 2018). Са некрополе Пећине потиче рељефни печат Ц-10659 са ромбом лучних ивица уписаним у круг, кругом у средини и очуваним кругом у једном углу (Кат. 9, Т. II. 4, сл. 2. 4). ${ }^{6}$ Најближа аналогија је случајни налаз са локалитета Чаир (Кат. 8, Т. II. 3) датован у период 2. и 3. века (Миловановић 2005, 300 , сл. 4/1). Аналогни примерак нађен је на локалитету Зидине на Вису (Issa) (Buljevic, Z. 2011, P1. 4, CRO/SP 13; Fadić, Štefanac 2012, kat. br. 140, T. XXIV), док су у југозападном делу Француске (Cabart, Foy, Nenna 2006, 89, P1. 5, F-CAR 024-025) и источном делу Крима (Шабанов 2017. 95, рис. 3.4, $3.5)$ евидентирани рељефи са ромбом који није уписан у круг, датовани у 2. век. Калуп са сличним мотивом нађен је у радионици у Апулуму (Apulum, Dacia Apulensis) (Pánczél 2011, Pl. 2/17).

\footnotetext{
${ }^{4}$ У жртвеном слоју је откривен разноврстан покретни материјал, између осталог и: жижак са печатом FORTIS (1-3. век), жижак са печатом ARMENI (2-3. век), стаклена мешалица (1-3. век) и бронзане монете датоване у период 1-3. века. (Дневник теренских ископавања, стр. 1012; Vojvoda, Mrđić 2015).

${ }^{5}$ Некропола је датована на основу монета Нерона, Тајана, Фаустине Старије и Антонина Пија (Ljubić 1882, 3, 4).

${ }^{6}$ Дно боце Ц-10659 нађено је у слоју земље која се налазила изнад нивоа инхумираних гробова (Дневник теренских ископавања, стр. 2675).
} 
Широм Царства откривени су примерци боца који на свом дну имају разнолике флоралне мотиве: стилизоване, ређе реално приказане мотиве бршљенових листова, венаца, гранчица, палмета и розета. На виминацијумским примерцима заступљен је мотив розете. Розета је често коришћена, најчешће на Медитерану и у северноалпским областима. Забележено је више варијанти са листовима/латицама различитог броја, облика и величине. Јавља се самостално или уписана у круг, са круговима или полукруговима у угловима или између листова/латица, могу бити изведене у виду кругова који својим распоредом обликују стилизован цвет, издуженог или троугластог облика, попут лопатица или пропелера (Cabart, Foy, Nenna 2006, 56, Pl. 15, F-CAR 129; Fadić, Štefanac 2012, 15, kat. br. 126-131). На дну виминацијумске боце Ц-9176 откривене на некрополи Пећине у оквиру жртвене површине, ${ }^{7}$ налази се печат са мотивом два концентрична круга у коме је изведена честворолисна розета са кружићем у средини и круговима на угловима (Кат. 6, Т. II. 1, сл. 2. 1). Мотиви четворолисних и петолисних розета уобичајени су у Панонији (Dévai 2019, 250), али се начин израде печата може упоредити са печатима са шестолисном розетом откривеним на Караташу (Diana) (Ružić 1994, 11, T. I/3), у Панонији (Barkóczi 1988, 177-178, taf. XXXVIII, 422, 423, 424; Lazar 2003, fig. 45.9), Германији (Dévai 2019, 251), Галији (Cabart, Foy, Nenna 2006, Pl. 14, F-CAR 120-123), Португалији (Alarcão 1975, cat. 29), понтској Олбији (Шабанов, С.Б. 2017. 95, рис. 3.3). Ови примерци су датовани у 2. век. У Апулуму (Pánczél 2011, Pl. 1/7.2) и Бону (Dévai 2019, 251 , са нап. 7) нађени су калупи са представом шестолисне розете са кружићем у центру. Мотив четворолисне розете која није уписана у круг откривен је у Салони (Buljević 2011, 180, CRO-SP 16; Buljević 2019, 111, sl. 17; Fadić, Štefanac 2012, kat. 175, T. XXVIII), на некрополи у Задру (Fadić, Štefanac 2012, kat. 173, T. XXVIII; Gluščević 1998, 1/grob 320) и Асерији (Buljević 2011, str. 179, CRO-SP 7; Fadić, Štefanac 2012, kat. 174, Т. XXVIII). Виминацијумски примерак Ц-8779 са четворолисном розетом чији су листови зракасто постављени, а између њих се налазе два срцолика орнамента, потиче из жртвене површине са некрополе Пећине (Кат. 7, Т. II. 2, сл. 2. 2). ${ }^{8}$ Сличан орнамент налази се на дну квадратне боце нађене у Цаски на острву Пагу (Cissa). Четворолисна розета је врло слично изведена, али без орнамената између листова (Fadić, Štefanac 2012, kat. 185, Т. XXIX). Карактеристичан мотив у виду шест троугластих латица са врховима окренутим

\footnotetext{
7 Дно Ц-9176 нађено је у оквиру жртвене површине у сонди 340, на релативној дубини 1,55 м, датоване монетама од Домицијана до Марка Аурелија (Дневник теренских ископавања, стр. 2350; Vojvoda, Mrđić 2017).

${ }^{8}$ Дно Ц-8779 нађено је у оквиру жртвене површине у сонди 340, на релативној дубини 0,55 м. На истој релативној дубини нађени су фрагменти керамичких жижака, од којих је на једном примерку сачуван део печата FO(RTIS) (1-3. век) (Дневник теренских ископавања, стр. 2272).
} 
ка центру и троугловима на угловима налази се на фрагменту дна боце Ц-4368 нађене на некрополи Више гробаља (Кат. 3, Т. І. 3, сл. 1. 3). ${ }^{9}$ На дну се налази полумесечасти траг металног држача. Розета са латицама у виду пропелера забележена је у Галији (Cabart, Foy, Nenna 2006, 56, Pl.15, F-CAR.129), али се облик и израда не могу упоредити са виминацијумским примерком.

\section{Значење и функција рељефних печата}

Новија истраживања и бројне публикације дали су значајан допринос проучавању рељефних печата и омогућили лакше сагледавање дистрибуције, повезивање посуда са радионицама и стакларима те лакше тумачење њиховог значења. Луиђи Таборели претпостављао је да се ознаке на дну односе на садржај боца или на произвођача садржаја, а не на радионицу или власника (Taborelli, L. 2006). Такође, рељефни мотиви постављени унутар или ван концентричних кругова, првобитно су тумачени као показатељи капацитета. Међутим, детаљније анализе су показале да се ови рељефни детаљи могу сматрати декоративним, односно функционалним елементима, јер су постављани на месту које доприноси стабилности боца (Barbera 2011: 112). Рељефни печати се могу интерпретирати као ознаке стакларских радионица, односно власника, на шта указују и можда најзначајније ознаке, натписи са именима ${ }^{10}$, на основу којих се могло закључити да се печати односе на стаклара који је посуду израдио или радионицу у којој је стварао. ${ }^{11}$ Такође, натписи са грчким писмом могу да укажу на производњу у источ-

\footnotetext{
9 Дно Ц-4368 нађено је у сонди 84, на релативној дубини 0,4 м, у слоју мрке земље, са већом количином фрагментованих керамичких посуда. На истој релативној дубини нађена је бронзана монета датована у период 2-3. века (Дневник теренских ископавања, стр. 887; Vojvoda, Mrđić 2015, cat. 2128).

${ }^{10}$ На бројним примерцима који потичу из северне и централне Италије, Тиренске обале, околине Рима и са далматинске обале, од Задра до Кварнерског залива (Buljević 2006; Buora 2006, 205; Fadić, Štefanac 2012, 18, kat. 211-214, T. XXXIII), налази се име L. AEMILIUS BLASTIUS. Име овог стаклара присутно је и на мањем броју примерака нађеним у средњем и горњем Подунављу (Barkoczi 1988, 176, taf. XXXVIII, 413). Име C. SALVIUS GRATUS налази се на посудама које су биле у оптицају крајем I и почетком II века у северној Италији, од јадранске обале до кантона Тичино, у Лигурији, а нађене су и у Галији, Норику, Рецији, Далмацији и на локалитетима дуж тока реке Дунав (Buljević 2011, 180; Cabart, Foy, Nenna 2006, 61; Fadić, Štefanac 2012, 18, kat. 216-217, T. XXXIV; Foy 2015, 361; Pastorino 2007, 194; Romagnolo 2013, 472). За радионице северне Италије везује се и стаклар CN. POMPEIUS CASSIANUS (Buljević 2009; Fadić, Štefanac 2012, 18, kat. 215, T. XXXIII). На источној Јадранској обали евидентиран је и отисак имена са грчким алфабетом $\mathrm{A} \Lambda^{\prime} \mathrm{E} \Xi \mathrm{AN} \Delta \mathrm{PO} \Sigma$ - Alexandros (Štefanac 2012, 18, kat. 221, T. XXXV).

${ }^{11}$ Пар боца правоугаоног реципијента са ознаком SENTIA SECUNDA FACIT AQ(UILEIA) VITR(A) на дну, откривених у Линцу, интересантан су и врло значајан налаз, јер не само да сведочи о жени која је била задужена за производњу, већ повезује производњу посуда са одређеном особом и прецизира место производње (Cool, Price 1995, 184).
} 
ним радионицама, док би натписи и имена на латинском указивали на западно порекло. Често се, у различитим, међусобно удаљеним областима, могу наћи посуде са именима истог стаклара и истим или врло сличним печатом, израђене од истих сировина, што сугерише на могућност размене калупа између радионица (Buljević 2005, 95; Stern 1995, 71; Stern 1999, 459), као и трговину сировинама. ${ }^{12}$

\section{Хронологија и порекло квадратних боца}

Иако је квадратна боца једна од најзаступљенијих стаклених посуда широм Царства, питање почетка производње је и даље проблематично. Морен-Жан почетак производње ставља у период Августа (Morin-Jean 1913, 61), док је Класина Исингс сматрала да почетак производње одговара времену Клаудија (Isings, С. 1957, 63). По Дебори Чарлсворт квадратне боце се нису појавиле много после владавине Клаудија и као најстарије примерке овог типа наводи примерке из Хофхајма и Колчестера (Camulodunum) (Charlesworth 1966, 30, Cool, Price 1995, 211). Појава боца квадратног реципијента из Колчестера смештена је у период од 43 до 60 године (Cool, Price, 1995, 213, fig. 13). Примерци из Косе $(\operatorname{Cos} a)$ (Cool, Price 1995, 184) и олупине брода Port-Vendres II (Cool, Price 1995, 184; Colls 1977, 120, no 9, fig 42) употребу квадратних боца померају на почетак владавине Клаудија, док јединствени налаз квадратних боца у Магдаленсбергу, откривен у слоју из периода Августове владавине, њихову појаву помера у прве деценије 1. века (Cool, Price 1995, 184). Мишљења о пореклу квадратних боца такође су подељена. На основу великог броја откривених боца на појединим налазиштима широм Царства, као центри производње се наводе Сирија и Кипар, могуће централна Италија и Галија, коју многи аутори сматрају центром производње (Fadić 1988, 39 са нап. 74). У западним провинцијама најинтензивнији период производње био је између 70 и 120/130. године, међутим, бројни примерци откривени широм Царства у слојевима датованим у другу половину 2. века указали су на њихову производњу и у овом периоду (Cool and Price 1995, 185). Током 3. века употреба

\footnotetext{
${ }^{12}$ Новија истраживања која обухватају примену метода за утврђивање хемијског састава стаклених посуда омогућила су дефинисање порекла и састава сировина, самим тим и праћење и анализу посуда, од примарне производње, до престанка употребе. Анализе састава римског стакла из различитих области и из различитих периода показале су униформност хемијског састава, што наводи на закључак да сировина коришћена за израду стакла у различитим радионицама, у различитим областима, припада једном извору и да је највероватније дистрибуирана из неколико примарних радионица (Buljević 2005, 98; Stern 1999, 454), које су археолошки потврђене само на истоку, на обалама Леванта и у Египту и припадају периоду од 4. до 8. века (Ganio et al. 2012, 98, Nenna et al. 2000, 97-112). У потопљеном античком броду недалеко од острва Мљет, нађена је велика количина стаклене сировине. Терет је највероватније био намењен извозу, вероватно ка Отранту и даље према Средоземљу (Fadić 2004, 96).
} 
квадратних боца била је ређа, а у 4. веку њихова употреба се прати на налазиштима источног Медитерана, док се у западним провинцијама спорадично јављају (Barbera 2011, 113). Један од најмлађих примерака из западног дела Царства нађен је у Келну (Colonia Agrippinensis, Germania Inferior), а датован је у прву половину 4. века (Isings 1957, 67). Боце квадратног реципијента биле су, у мањем броју, присутне и на простору касноримске Далмације ${ }^{13}$ (Fadić 1999-2000, 185-194) и Паноније (Dévai 2016, 265, Pa6. 1B, са нап. 52). Са некрополе у Шагвару (Ságvár, Tricciana, Pannonia Inferior) потичу примерци опредељени у период између 337. и 375. године (Каровић 1995-96, 77, са нап. 15). На основу броја и уједначености квалитета израде појединих касноримских типова, између осталог и боца са квадратним реципијентом код којих је уочено да су израђене без рељефних орнамената на дну, претпостављено је да су посуде производ локалних радионица (Barkóczi 1988, 171; Dévai 2016, 267). У односу на западне делове Царства, у источним деловима откривен је мањи број квадратних боца, али се њихова употреба може пратити и кроз период касне антике. И у источним провинцијама потврђена је њихова рана употреба. Боце са острва Самотрака датоване су у време цара Клаудија ${ }^{14}$ (Dunsebery 1967, 47, fig. 46). Примерци из Кнососа датовани су у период Флавијеваца (69-96) ${ }^{15}$ (Carington Smith 1982, 277, 278, 58, fig. 5:58; Price 1992, 424, Pl. 342, 119). У Солуну су откривене боце датоване у последње две деценије 1. века (Antonaras 2010, 243, fig. I/5). Као производ источномедитеранских радионица (Кипар или Дура Еуропос?) наводе се боце из Будве (Butua, Dalmatia), чија се употреба ограничава на период 1. века (Veličković 1974, 169, sl. 12, 13. 14). Употреба квадратних боца у источном Медитерану траје и током 3. века, а производњу у 4. веку потврђују различите варијација типа Isings 50, са различито обрађеним ободима ${ }^{16}$, откривене у Каранису. У античкој Ликији потвр-

\footnotetext{
${ }^{13}$ На простору Далмације пронађено је пет фрагмената квадратних боца са рељефним печатима са хришћанском симболиком, крстом и Христовим монограмом. Приближно су датовани у период од краја 2. до почетка 4. века (Fadić 1999-2000, 188-189).

${ }^{14}$ Боце су откривене у затвореним целинама; једна је откривена у јами из времена Флавијеваца Price 1992, 424, P1.342, 119), а друга у породичној гробници, која је била у употреби од средине 1. века, на шта указују монете емитоване 54/55 г. Почетна година емитовања се не узима као почетак коришћења гробнице, већ се предлаже 60/65 г. на основу трагова дужег коришћења на монетама. На основу анализа сахрана и прилога претпостављено је да је гробница коришћена око 30 година (Carington Smith 1982, 268).

${ }^{15}$ Квадратне боце са Самотраке и из Кнососа рађене су од изузетно танког стакла у техници слободног дувања, са неукрашеним дном. Техника израде указује на производњу у некој од источномедитеранских радионица.

${ }^{16}$ У Каранису је нађен мали број боца идентично профилисаног обода, чија је производња почела у другој половини 3. и трајала током 4. века, али се ове боце могу везати искључиво за Каранис (Charlesworth 1966, 32).
} 
ђена је употреба квадратних боца у 5. веку (Tek 2000, 82-87), а дужу употребу ових боца потврђују и бројни примерци са атинске Агоре, датоване у период од друге половине 1. до 6. века (Weinberg, Stern 2009, 157, 158). Касноантички примерци евидентирани су на бројним источномедитеранским налазиштима (Weinberg, Stern 2009, 157).

\section{Типологија и технике израде}

Квадратне боце (тип Isings 50) карактерише реципијент квадратних или правоугаоних зидова, хоризонтално разгрнут, прстенасто профилисан или заравњен обод, кратак цилиндрични врат, шира тракаста дршка која може бити канелована или ребраста са различитим бројем ребара, савијена под правим или оштрим углом (Isings 1957, 63; Morin-Jean 1913, 61). Дршка је прављена одвојено и наношена на вруће стакло (Pánczél 2011, 179; Romagnolo 2013, 470). Студиозно проучавање квадратних боца Деборе Чарлсворт омогућило је одређивање типова на основу облика обода, дршке и реципијента. Као најранији тип квадратних боца препознате су боце реципијента скоро идентичне ширине и висине (тип Isings 50a), што је потврђено и налазима из Аугусте Раурике (Colonia Augusta Rauricorum) и Магдаленсберга (Magdalensberg, Noricum) (Barbera 2011, 113, са нап. 26, 27). У време владавине Флавијеваца (69-96) започета је производња боца издуженог реципијента (тип Isings 50b), о чему сведоче бројни налази широм Царства (Isings 1957, 66; Weinberg, Stern 2009, 110). Реципијент је рађен техником дувања у отворен петоделни калуп од теракоте или камена, док су раме, врат и обод израђени слободним дувањем. У употреби је била и техника слободног дувања, након чега су зидови и дно заравњени притискивањем на глатку површину. Старије претпоставке о морфолошким и хронолошким разликама као показатељима порекла показале су се као неутемељене. ${ }^{17}$ Новија истраживања указују да се коришћење техника дувања у калуп и слободног дувања углавном хронолошки преклапају, као и да се не може тврдити да су боце израђене у техници дувања у калуп производ западних радионица, а слободно дуване оних источних. Већи су изгледи да су се боце израђене слободним дувањем више користиле на Медитерану и у областима које се граниче са њим, него у северозападним провинцијама. Током периода највеће употребе квадратних боца, од средине 1. и кроз 2. век, у западним провинцијама доминантне су биле боце израђене у техници дувања у калуп, док су се у Грчкој и источним деловима Царства подједнако користиле и једне и друге

\footnotetext{
${ }^{17}$ Изнесене су претпоставке да су боце тањих зидова, зеленкасте боје стакла могле бити производ радионице у Аквилеји, док су боце дебљих зидова плаво-зелене боје стакла потицале из галских радионица (Calvi 1968, 81; Damevski 1974, 63, T.IV. 1, 2, са нап. 12).
} 
(Weinberg, Stern 2009, 111). Од техника израде зависиле су дебљина зидова и изглед реципијента, самим тим и капацитет боце. Боце рађене у калупу имале су дебље зидове, реципијент је имао оштрије ивице, а дна су углавном имала рељефне печате. Боце рађене техником слободног дувања имале су заобљенији реципијент, врат незнатно утонуо у косо раме услед притиска како би се поравнало дно, и рађене су од тањег стакла (Charlesworth 1966, 28). За складиштење и транспорт били су погоднији примерци дебљих зидова, а ради лакшег паковања већина је имала једну дршку. У кући Менандра у Помпеји и у вили Боскореале, у предграђу Помпеје, нађени су дрвени сандуци са боцама квадратног реципијента, спакованим и припремљеним за транспорт. Анализа садржаја из две боце показала је да је у њима похрањено маслиново уље (Barbera 2011, 113; Romagnolo 2013, 471). Облик боца је омогућавао максимално коришћење простора, али саме боце нису рађене по одређеним стандардима; због разлика у величини реципијента и дебљини стакла нису се могле користити као јединице мере. На основу разлика у величини и капацитету претпостављено је да су у њима, осим вина и уља, транспортоване и друге течности (Dévai 2019, 249, са нап. 2).

Виминацијумски примерци рађени су у техници дувања у калуп, од дебљег стакла плаве (Ц-3738, Ц-9176, Ц-10659), плавичасто-зеленкасте (Ц-290, Ц-4368) и бледо зеленкасте боје (Ц-5082, Ц-8779, случајни налаз). Издваја се дно боце Ц-10543, рађено од стакла средње дебљине, прозирног, скоро деколорисаног, зеленкасте нијансе. На два примерка (Ц-4368, Ц-5082) констатовани су трагови металног држача, којим је држана посуда како би се обликовали врат и обод (Stern 1999, 446). Након одвајања посуде и држача, траг држача је могао да остане или је уклоњен полирањем.

\section{Завршна разматрања}

Усавршавање стакларских техника почетком нове ере допринело је масовнијој производњи посуда од стакла и доступности нижим слојевима друштва, на шта указује просторна анализа материјала у Херкулануму и Помпеји (Barbera 2011, 113; Prior 2015). Освајање нових територија резултирало је формирањем војних логора и нових насеља, праћено доласком трговаца и занатлија из свих делова Царства, а дистрибуција квадратних боца пратила је главне речне и копнене комуникације па се највећи број ових боца налази на локалитетима у долини река и дуж најважнијих путева (Prior 2015; Romagnolo 2013, 472; Ružić 1994, 11-12). Не искључује се ни могућност да су и легионари, поред неопходне опреме, са собом носили и предмете за свакодневну употребу и транспорт одређених намирница. Због тога и не изне- 
нађује њихово присуство у насељима, некрополама и војним утврђењима на обали Саве и Дунава: у Сирмијуму (Цермановић Кузмановић 1981, 15, кат. 15-17, T. I, 15), Сингидунуму (Николић 1990, T. IV/35-38, T. V/39), Трикорнијуму (Ђорђевић 1996, 171-174), Маргуму (Каровић 1995-96. 77, 78, Т. I, 1-3), Виминацијуму, Новама, Трансдијерни, Дијани, Понтесу, Егети, у утврђењу Мора Вагеи (Ružić 1994, 11-12). Фрагменти ових боца нађени су и у унутрашњости провинције, у Тимакум Минусу и Улпијани (Ružić 1994, 12). За разлику од виминацијумских примерака, међу којима доминирају мотиви ромба и розете, на примерцима са локалитета дуж Ђердапског лимеса и у унутрашњости провинције Мезије, евидентирани су рељефи у виду концентричних кругова (Ružić 1994, kat. 3, 5, 7, 11, 14, 17-18, 23-24, 28-30), затим комбинације концентричних кругова и кругова на угловима (Ružić 1994, kat. $6,20)$. Ове ознаке се могу наћи широм Царства, а бројне су у приморском делу Далмације и северној и централној Италији (Fadić, Štefanac 2012, 9, kat. 1-77). Поред ових мотива, евидентирани су примерци са малим круговима на угловима (Ružić 1994, kat. 4, 20). Примерци са овим ознакама нађени су широм источног Медитерана и у црноморским областима, а велики број посуда са овим печатом нађен је на некрополи у Задру (Glišćević 1988, 182 184, fig. 1, graves: 304, 320, 452, 19; Fadić, Štefanac 2012, 10, kat. 78-100) и њихово порекло можемо тражити у радионицама у источним провинцијама. Најмањи број примерака је са ознакама у виду розета уписаних у круг (Ružić 1994, kat. 9, 13), али ниједна се не може упоредити са виминацијумским примерцима. Дистрибуција налаза може да укаже на путеве транспорта, у овом случају на речни транспорт Савом и Дунавом, којима је Виминацијум био повезан са осталим деловима Царства. До насеља у унутрашњости производи су допремани копненим саобраћајницама, мада треба узети у обзир и могућност речног транспорта реком Нишавом, која је, према натпису регрута речне флоте VII Клаудијеве легије (legio VII Claudia) из Наисуса (Naissus), била пловна (Петровић 2014, 136, са нап. 33). Квадратне боце коришћене су као амбалажа, уз амфоре као примарно транспортно средство, а у Виминацијум и друга насеља и војна утврђења, могле су доспети и као приватно власништво појединаца. Питање порекла квадратних боца и радионичких центара остаје отворено, јер анализа на основу аналогија малог броја виминацијумских примерака не може понудити коначно решење. Типолошка анализа стаклених посуда из Виминацијума показала је присуство посуда из различитих делова Царства. Забележен је импорт из галских, северноиталских и источномедитеранских радионица у периоду од средине 1 . до средине 3. века (Ропкић 2006, 375-380; Ропкић Ђорђевић 2012, 259-278; Ропкић 
Ђорђевић 2020, 333-347). Сличност у изради рељефних печата виминацијумских квадратних боца са примерцима из северне Италије и Француске, првенствено печата у виду ромба и печата са латиничним натписом, указују на везе Виминацијума и западних провинција, врло могуће преко Аквилеје. Рељефни печат у виду ромба лучних страна, са елипсоидним орнаментима на угловима, има аналогије у примерцима из Паноније, са непознатог налазишта и из Птуја, где је потврђена локална производња у периоду 2. и 3. века и где су евидентирани фрагменти са рељефним печатима у виду вишелатичних розета уписаних у круг (Lazar 2003, 230, Pl. 1: 6-8; Lazar 2001, 81). Ова чињеница отвара питања увоза и трговачких веза Виминацијума и панонских центара и радионица. Неколико виминацијумских примерака има сличности са рељефним печатима евидентираним у приобалном делу Далмације. Дно боце Ц-8779 са рељефним печатом у виду четворолисне розете, по изгледу и обради печата и боји стакла, врло је слично примерку нађеном у Киси на острву Пагу (Fadić, Štefanac 2012, kat. 185, Т. XXIX). Велики број рељефних печата у виду једноставне четворолисне розете која није уписана у круг (Fadić, Štefanac 2012, 17, kat. 173-180, 185-186, 194, 201-202), као и печати са тачкастим испупчењима у угловима и средини (Fadić, Štefanac 2012, 15, kat. 101-134), нађени су на простору Либурније, што указује на постојање локалних радионица на овом простору у периоду од друге половине 1. до краја 3. века, највероватније у Асерији, Јадеру и Енони (Fadić 2002, 388; Fadić, Štefanac 2009, 206-210), (Fadić 2004, 102). Још један виминацијумски примерак, Ц-10659, са печатом у виду ромба лучних страна уписаним у круг, кругом у средини и очуваним кругом у углу, компаративан је примерку са Виса (Fadić, Štefanac 2012, kat. 185, T. XXIX). У Далмацији је, за сада, потврђена производња стаклених посуда у Салони (Buljević 2005, 97, са нап. 40). Евентуално присуство посуда за које се може претпоставити да су производ либурнијских радионица може се објаснити и преласком легионара из провинције Далмације у Мезију, који су са собом, осим опреме, носили и предмете за свакодневну употребу, између осталог и предмете за складиштење и транспорт хране и течности.

Најранија употреба боца са квадратним реципијентом у Виминацијуму поклапа се са доласком VII Клаудијеве легије (legio VII Claudia) и боравком легије IV Флавијеве легије (legio IV Flavia) и може се пратити до почетка 3. века, што је хронолошки оквир аналогних посуда из западних провинција, као и примерака са локалитета у Србији (Цермановић Кузмановић $1981,15,16$, Николић 1990, 50). За сада не постоје елементи који би указали на рано успостављање локалне производње. Може се очекивати 
да је Виминацијум, као најзначајнији урбани центар са развијеном радионичком делатности и дистрибутивном мрежом, имао и радионицу за производњу стаклених посуда, на шта указује велика заступљеност и униформност појединих облика, посебно балсамаријума, ${ }^{18}$ али не пре периода стицања статуса колоније у 3 . веку. За сада је производња стаклених посуда у касноантичком периоду потврђена само у Сирмијуму (Milošević 1974, 102-108), а постоје индиције да је радионица било и на Космају (Marić Stojanović et al. 2015, 54), Хисару (Пешић et al. 2004/5, 37) и Улпијани (Ružić 1994, 63).

\section{Каталог}

1. Дно боце (Т. I.1; сл. 1.1)

Локалитет Велика капија (1979), Ц-290, Сонда XXII

Инв. бр. ЦР 5590

Дим. 5,2 х 5,5 цм

Фрагмент удубљеног дна призматичне боце рађене од прозирног стакла плавичасто-зеленкасте боје, са рељефним натписом у два реда $\mathrm{CA}(\mathrm{I}) \mid(\mathrm{N}) \mathrm{E}$.

Датовање: прва половина 3. века

Непубликовано.

2. Дно боце (Т. I.2; сл. 1.2)

Локалитет Више гробаља (1984), Ц-3738, Сонда 68

Инв. бр. ЦР 2566

Дим. 6,7 х 7,3 цм

Фрагмент благо удубљеног дна боце рађене од прозирног стакла плаве боје, са рељефном представом четвороножне животиње (пас?) и делом натписа SOL (ретроградно) изнад леђа.

Датовање: 2-3. век

Публиковано: Zotović, Jordović 1990, 27, sl. 12.

\footnotetext{
${ }^{18}$ На могућност постојања радионице указује присуство стаклене шљаке и велики број посуда, посебно балсамаријума уједначеног квалитета, као и скелет мушкарца старог око 35 година, са абразивним променама на зубима, за које се претпоставља да се могу везати за професију дувача стакла (Мucić 1990, 28). Изузетни геолошки услови на ужој и широј територији Виминацијума, као и чињеница да је почетком 20. века у Костолцу постојала фабрика стакла која је радила до 1915. године (Фелдић 1989-90, 23) представљају реалну основу за ову претпоставку.
} 
3. Дно боце (Т. І.3; сл. 1.3)

Локалитет Више гробаља (1984), Ц-4368, Сонда 84

Инв. бр. ЦР 2419

Дим. 8 × 8 цм

Фрагмент благо удубљеног дна боце рађене од прозирног стакла плавичасто-зеленкасте боје, са рељефном представом у виду шестокраке розете са врховима окренутим ка центру. На угловима постављени троуглови. На дну траг металног држача.

Датовање: 2-3. век

Непубликовано.

4. Дно боце (Т. I.4; сл. 1.4)

Локалитет Више гробаља (1984), Ц-5082, Сонда 91

Инв. бр. ЦР 2414

Дим. 6 х 6 цм

Фрагмент благо удубљеног дна боце рађене од прозирног стакла зеленкасто-жућкасте боје, са рељефном представом у виду ромба лучних страна и круговима на угловима. Делимично очуван круг у једном углу. На дну траг металног држача.

Датовање: 1-3. век

Непубликовано.

5. Дно боце (Т. I.5; сл. 2.3)

Локалитет Пећине (1983), Ц-10543, Сонда 358, Г-3485

Инв. бр. ЦР 2486

Дим. 8,1 х 8,1 цм

Фрагмент благо удубљеног дна и реципијента боце рађене од прозирног, скоро деколорисаног стакла зеленкасте нијансе, са рељефном представом у виду ромба лучних страна, са кружићем у средини и елипсоидним орнаментом на угловима.

Датовање: 2-3. век

Непубликовано.

6. Дно боце (Т. II.1; сл. 2.1)

Локалитет Пећине (1983), Ц-9176, Сонда 340

Инв. бр. ЦР 2521

Дим. 8 × 8 цм

Фрагмент удубљеног дна и реципијента боце рађене од прозирног стакла плаве боје, са рељефном представом у виду четворолисне розете са кружићем у средини, оивиченом са два концентрична круга и кружићима на угловима. 
Датовање: 2-3. век Непубликовано.

7. Дно боце (Т. ІІ.2; сл. 2.2)

Локалитет Пећине (1983), Ц-8779, Сонда 340

Инв. бр. ЦР 2507

Дим. 8,9 х 9,3 цм

Фрагмент удубљеног дна и реципијента боце рађене од прозирног стакла бледозеленкасте боје, са рељефном представом у виду четворолисне розете са зракасто постављеним латицама и два очувана срцолика орнамента између листова.

Датовање: 2-3. век

Непубликовано.

8. Дно боце (Т. II.3)

Локалитет Чаир, случајни налаз

Инв. бр. ЦР 2241

Дим. 5,5 х 4,5 цм

Фрагмент удубљеног дна и реципијента боце рађене од прозирног стакла бледозеленкасте боје, са рељефном представом у виду ромба лучних страна, оивиченим кругом, са кругом у средини

Датовање: 2-3. век

Публиковано: Миловановић 2005, 300, сл. 4/1.

9. Дно боце (Т. II.4; сл. 2.4)

Локалитет Пећине (1983), Ц-10659, Сонда 358

Инв. бр. ЦР 2478

Дим. 5,8 х 6,6 цм

Фрагмент удубљеног дна боце рађене од прозирног стакла плаве боје, са рељефном представом у виду ромба лучних страна, оивиченим кругом, са кругом у средини. У једном углу очуван кружић. Датовање: 2-3. век

Непубликовано.

\section{БИБЛИОГРАФИЈА}

Alarcão, J. 1975. Bouteilles carees a Fond decore du Portugal Romain. Journal of Glass Studies Vol. 17: 47-53.

Arheološki muzej Istre. http:/www.ami-pula.hr/prozor-u-proslost/zigovi-na-dnu-staklenihkvadraticnih-recipijenata-praksa-koja-se-prati-od-antike/ (приступљено 18. 04. 2021) 
Barbera, M. 2011. Una bottiglia monoansata in vetro Isings 50/51 dall'Area E di Nora, “ $L A N X ”$ 9, Rivista della Scuola di Specializzazione in Beni Archeologici dell'Università degli Studi di Milano: 110-121.

Barkóczi, L. 1988. Romishe Glassfunde in Ungarn. Budapest: Akadémiai Kiadó.

Buora, M. 2006. Postilla su L. Aemilius Blasius (o Blastus), in: Convegno Le Regioni di Aquileia e Spalato in Epoca Romana, Castello di Udine 4 aprile 2006: 205-209.

Buljević, Z. 2005. Tragovi staklara u rimskoj provinciji Dalmaciji. Vjesnik za Arheologiju i Historiju Dalmatinsku 98: 93-106.

Buljevic, Z. 2006. Novità sul vetro soffi ato a stampo della Dalmazia con alcuni paralleli italici, in: Convegno Le Regioni di Aquileia e Spalato in Epoca Romana, Castello di Udine 4 aprile 2006: 163-184.

Buljević, Z. 2011. Imprints on the bottoms of glass bottles from Dalmatia held in the Archaeological Museum in Split, in: D. Foy, M-D. Nenna, (eds.). Corpus des signatures et marques sur verres antiques 3. Aix-en-Provence - Lyon: 179-195.

Buljević, Z. 2019. Salonitansko stakleno posuđe puhano u kalup. Izdanja Hrvatskog arheološkog društva 33: 99-126.

Cabart, H., Foy, D., Nenna, M-D. 2006. Les bouteilles et pots carrés, in: D. Foy, M-D. Nenna, (eds.). Corpus des signatures et marques sur verres antiques 1. Aix-en-Provance - Lyon: 73-107.

Calvi. M. C. 1968. I vetri romani del Museo di Aquileia. Aquileia: Associazione Nazionale per Aquileia.

Carington Smith, J. 1982. A Roman Chamber Tomb on the South-East Slopes of Monasteriaki Kephala, Knossos. The Annual of the British School at Athens 77: 255-293.

Цермановић Кузмановић, А. 1981. Античко стакло Сирмијума. Грађа за проучавағе споменика културе Војводине X: 7-29.

Charlesworth, D. 1966. Roman square bottles. Journal of Glass Studies Vol. 8: 26-40.

Colls, D., Etienne, R., Lequement, R., Liou, B. et Mayet, F. 1977. L'epave Port-Vendres II et le commerce de la Betique a I'epoque de Claude. Archaeonautica, 1. Paris.

Cool, H. E. M. and Price, J. 1995. Colchester Archaeological Report 8, Roman vessel glass from excavations in Colchester 1971-85. Colchester: Colchester Archaeological Trust.

Damevski, V. 1974. Pregled tipova staklenog posuđa iz italskih, galskih, mediteranskih i porajnskih radionica na području Hrvatske u doba Rimskog carstva. Arheološki vestnik XXV: 62-87.

Dévai, K. 2016. Glass vessels from Late Roman times found in Pannonia. Acta Archaeologica Academiae Scientiarum Hungaricae 67. Budapest, Akadémiai Kiadó: 255-286.

Dévai, K. 2019. Base-Marks, Impressed Designs, and Names on Square Bottles from Brigetio. Journal of Glass Studies Vol. 61: 249-253.

Dunsebery, E. 1967. Ancient glass from the cemeteries of Samothrace. Journal of Glass Studies Vol. 9: 34-49.

Ђорђевић, М. 1996. Стаклени крчаг из Ритопека. Гласник Српског археолошког друштва 12: 171-174. 
Fadić, I. 1988. Antičko staklo Asserije iz Arheološkog muzeja u Splitu. Benkovački kraj kroz vekove 2. Benkovac 22-24. April 1983. Benkovac: 29-70.

Fadić, I. 1999-2000. Žigovi kriptograma i križa na dnu staklenih kvadratičnih vrčeva (Christogram and cross stamps on the bases of square glass bottles). Opuscula archaeologica 23-24 (Sportula dissertationum Marino Zaninović dicata): 185-194.

Fadić, I. 2002. Antičke staklarske radionice u Liburniji. Godišnjak CBI, XXXII. Akademija nauka i umjetnosti Bosne i Hercegovine, knjiga 30. Sarajevo, Frankfurt am Main, Berlin, Heidelberg: 385-405.

Fadić, I. 2004. Antičke staklarske radionice u Hrvatskoj, u: Drobci antičkega stekla. Annales Mediterranea. Koper: 95-106.

Fadić, I., Štefanac, B. 2009. Workshop stamps on square bottles from the Zadar region. In: D. Ignatiadou, A. Antonaras (eds.). Annales du $18^{e}$ Congrès de l'Association Internationale pour l'Histoire du Verre. Thessaloniki, 21-25.09.2009. Thessaloniki, AIHIV: 206-210.

Fadić, I., Štefanac, B. 2012. Rimsko staklo Hrvatske - Radionički reljefni žigovi. Zadar. Фелдић, Д. 1989-90. Фабрика стакла у Костолцу. Viminacium 4-5: 223-224.

Foy, D. 2015. Les marques sur les récipients en verre découverts en Gaule: indices de production et de relations commerciales (milieu du Ier s.-Ve s. apr. J.-C.). Gallia 72/2: 351-401.

Ganio, M., Boyen, S., Brems, D., Giannini, R., Shortland, A., Vanhaecke F., Degryse, P. 2012. 'True' Roman Glass. Evidence for primary production in Italy. Annales $d u 19^{e}$ Congrès de l'Association Internationale pour l'Histoire du Verre. Piran 17-21.09.2012. Piran, AIHIV: 98-108.

Glišćević, S. 1998. Roman glass in Zadar: Certain characteristics forms. Annales $d u 14^{e}$ Congrès de l'Association Internationale pour l'Histoire du Verre. Italia/Venecia - Milano, 1998. AIHIV: 182-189.

Harden, D. 1936. Roman glass from Karanis found by the Universiti of Michigan Archaeological expedition in Egypt, Oxford.

Isings, C. 1957. Roman Glass from dated Finds. Archaeologica Traiectina II. GroningenDjakarta: J. B. Walters.

Каровић, Г. 1995-96. Римско стакло Маргума. Viminacium 10: 75-104.

Lazar, I. 2001. Roman glass production in Slovenia. Annales du $15^{e}$ Congrès de l'Association Internationale pour l'Histoire du Verre. New York - Corning 2001. AIHIV: 78-81. Lazar, I. 2003. Rimsko steklo Slovenije. Ljubljana: Inštitut za arheologijo ZRC SAZU. Ljubić, Š. 1882. Arheoločko iskopavanje u Bakru. Vjestnik Arheološkog muzeja u Zagrebu VI/1: 48-54.

Marić Stojanović, M., Šmit, Ž., Glumac, M., Mutić, J. 2015. PIXE-PIGE investigation of Roman Imperial vessels and window glass from Mt. Kosmaj, Serbia (Moesia Superior). Journal of Archaeological Science: Reports 1: 53-63.

Миловановић, Б. 2005. Случајни налази стаклених посуда из Виминацијума и околине. Гласник Српског археолошког друштва 21: 293-317. 
Milošević, P. 1974. Radionice stakla u Sirmijumu. Arheološki vestnik XXV: 102-108. Morin-Jean, A. J. 1913. La verrerie en Gaule sous l'Empire romain; essai de morphologie et de chronologie. Paris: H. Laurens.

Mucić, D. 1990. Slučaj profesionalne abrazije zuba sa nekropole antičkog Viminaciuma. Glasnik Srpskog arheološkog društva 6: 26-28.

Nenna, M.-D., Picon, M., Vichy, M. 2000. La route du verre: ateliers primaires et secondaires. Actes de la table ronde de 1997. Travaux de la Maison de l'Orient 33. Lyon 2000, 97-112.

Pánczél, S. P. 2011. The Production of Prismatic Glass Bottles in Roman Apulum. Marisia XXXI: 175-187.

Pastorino, A. M. 2007. I Vetri. Onde nulla si perda: la collezione archeologica di Cesare Di Negro-Carpani, a cura di A. Crosetto e M. Venturino Gambari, Alessandria: 187-367. Петровић, В. 2014. Централни Балкан у римским итинерарима. Тематски зборник радова - Савремене парадигме у науци научној фантастици Међународног научног скупа Наука и савремени универзитет 3 (ур. Б. Димитријевић). Филозофски факултет у Нишу. Ниш: 127-140.

Пешић, Ј., Јовић, С., Миљковић, М., Стојић, М. 2004/5. Археолошка ископавања на локалитету Хисар у Лесковцу. Археолошки преглед 2/3: 36-37.

Jordović, Č. 1980. Velika kapija-rimska nekropola i naselje. Arheološki pregled 21: 123-126.

Price, J. 1992. Hellenistic and Roman Glass in Knossos: From Greek City to Roman Colony: Excavations at the Unexplored Mansion 2. The British School at Athens. Supplementary Volumes. Oxford: 415-490.

Prior, J. D. 2015. The Impact of Glassblowing on the Early-Roman Glass Industry (circa 50 B. C. -A. D. 79), Durham theses, Durham University: http://etheses.dur.ac.uk/11186/. 


\title{
Antonija S. Ropkić Đorđević \\ Belgrade
}

\section{RELIEF STAMPS AT THE BOTTOMS OF SQUARE BOTTLES FROM THE NATIONAL MUSEUM IN POŽAREVAC}

\author{
Keywords: National Museum, Požarevac, Viminacium, \\ necropolis, square bottle, relief stamps
}

Fragments of nine relief stamps at the bottoms of mould-blown square glass bottles, Isings type 50, have been discovered during rescue excavations at the site of Viminacium between 1979 and 1984. Eight fragments were found at the southern necropoles of Viminacium, Više Grobalja, Pećine and Velika Kapija, and one came from the site of Cair, as a chance find. They were dated into the period from the middle of the $1^{\text {st }}$ century to the $3^{\text {rd }}$ century AD, on the basis of dated contexts from the necropoles, and on the basis of analogies from relief stamps found elsewhere in the Empire.

This small part of the National Museum's collections consists of various types of relief symbols: geometric and floral motifs with dots in the corners, zoomorphic reliefs and inscriptions. These symbols may represent the marks of a glassmaker or a workshop, but, according to the opinion of some, they may also be related to the content of the bottle or to the makers of a product. The inscriptions may be important guidelines, as the letters or names may refer to the maker or the place of manufacture. These stamps may provide valuable information about the origin, distribution and trade routes of square bottles.

Analogies for relief stamps from the National Museum's collections can be found among the material from Pannonia, Gaul, northern and central Italy and eastern Mediterranean region. There are certain similarities with relief stamps found in Roman Portugal, on sites along the Danube Valley in Moesia and Dacia and the coastal area of the Black Sea. Based on fragmented bottoms alone, it is not possible to tell where the bottles were made. They might have been products of workshops from northern and central Italy, Gaul or eastern Mediterranean region. There are some indications of Pannonian or Dalmatian origin too. This may indicate that Early Roman trade routes between Viminacium and both western and eastern provinces were developed. The presence of square bottles from a large number of sites, settlements, necropoles and military camps is not unusual, as they were used as containers for storage and transport of various types of liquids or semi-liquid materials. 
There is a certain number of arguments about the existence of local production in Viminacium in the Late Roman period, but based on the available information, there is no indication of the existence of a workshop in the Early Roman period. 

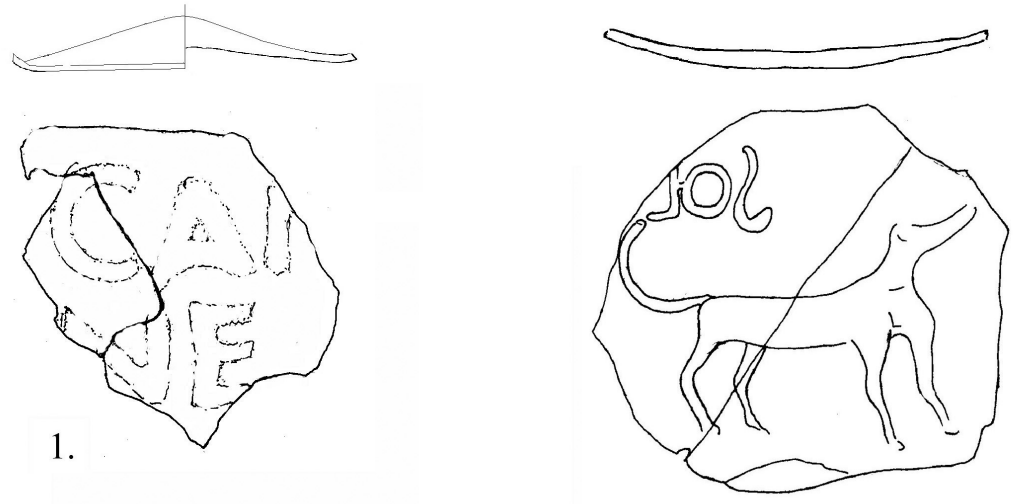

2.
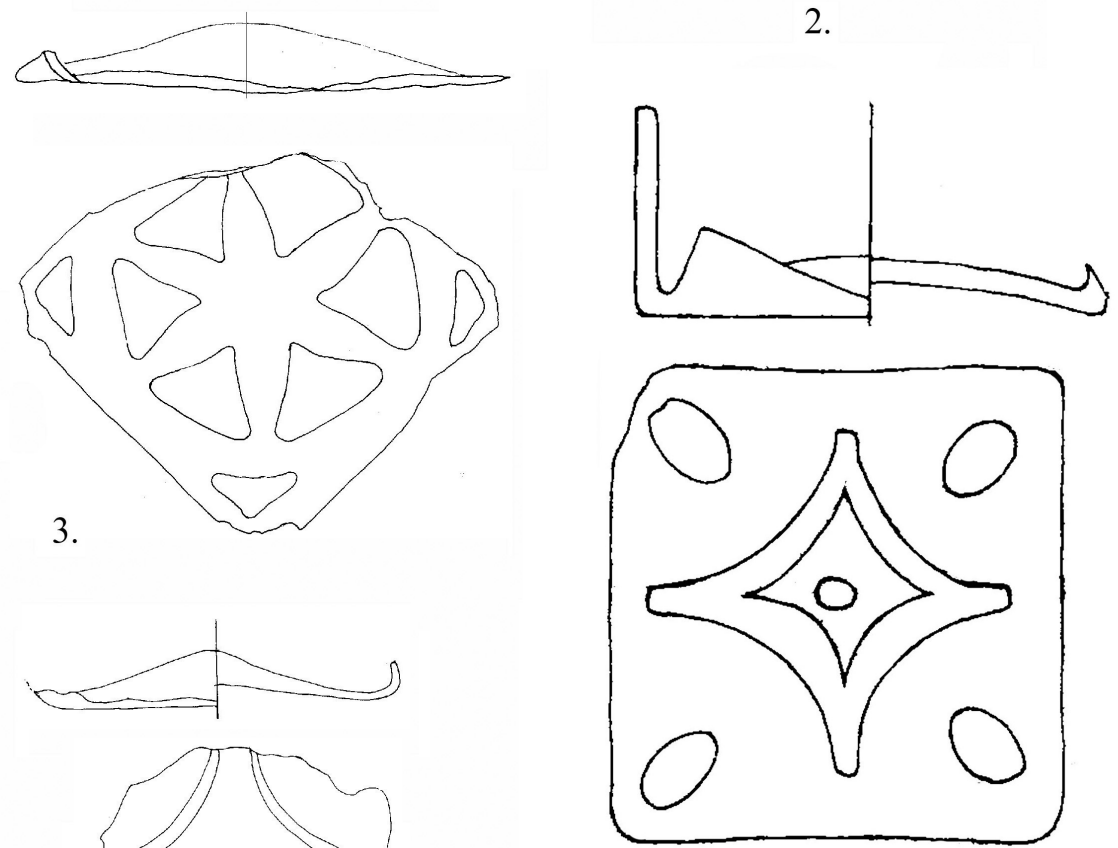

5.

4.
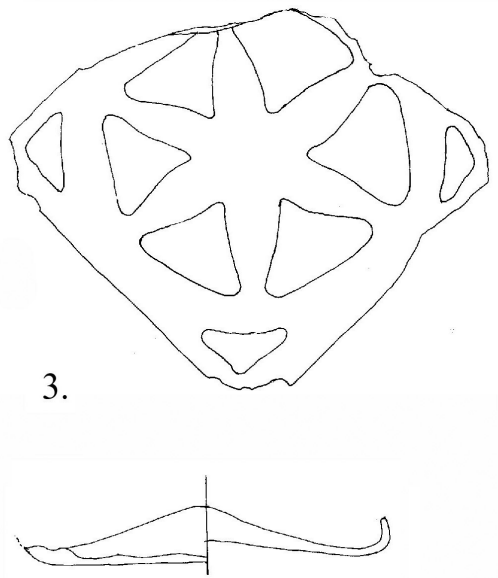

4.
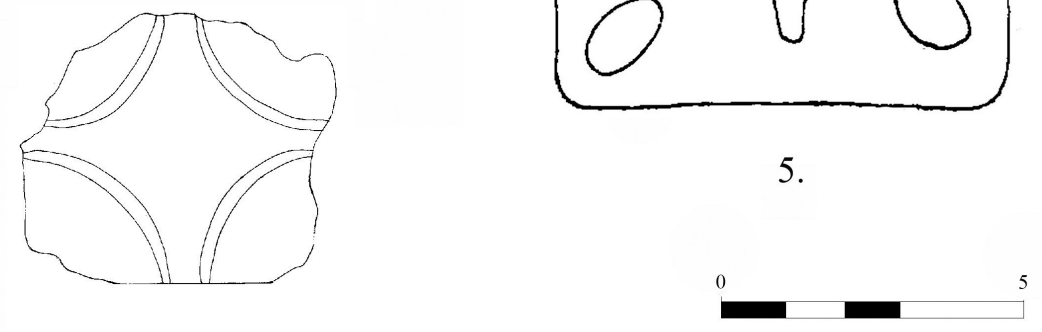

T. I 1. Локалитет Велика капија, 2-4. Локалитет Више гробаља, 5. Локалитет Пећине Pl. I 1. The site of Velika Kapija, 2-4. The site of Više Grobalja, 5. The site of Pećine 

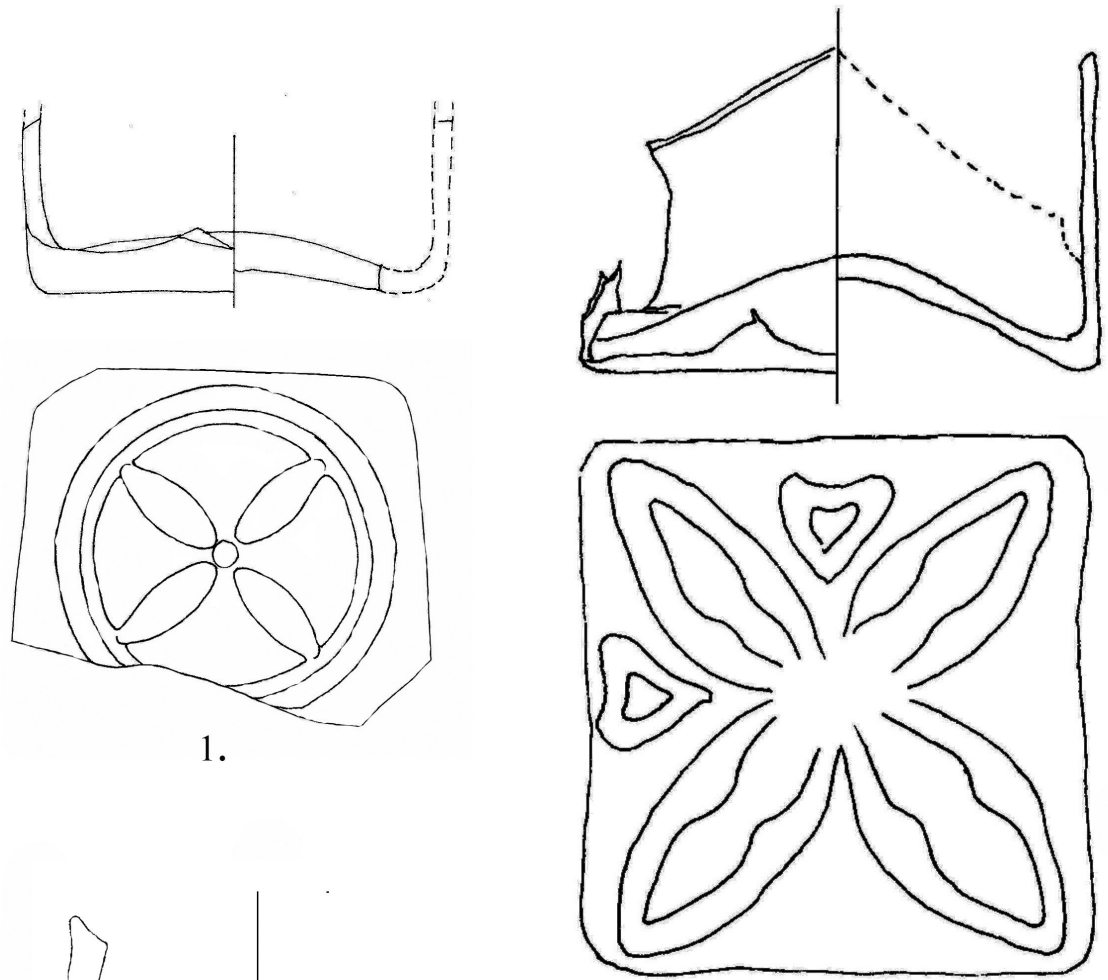

2.
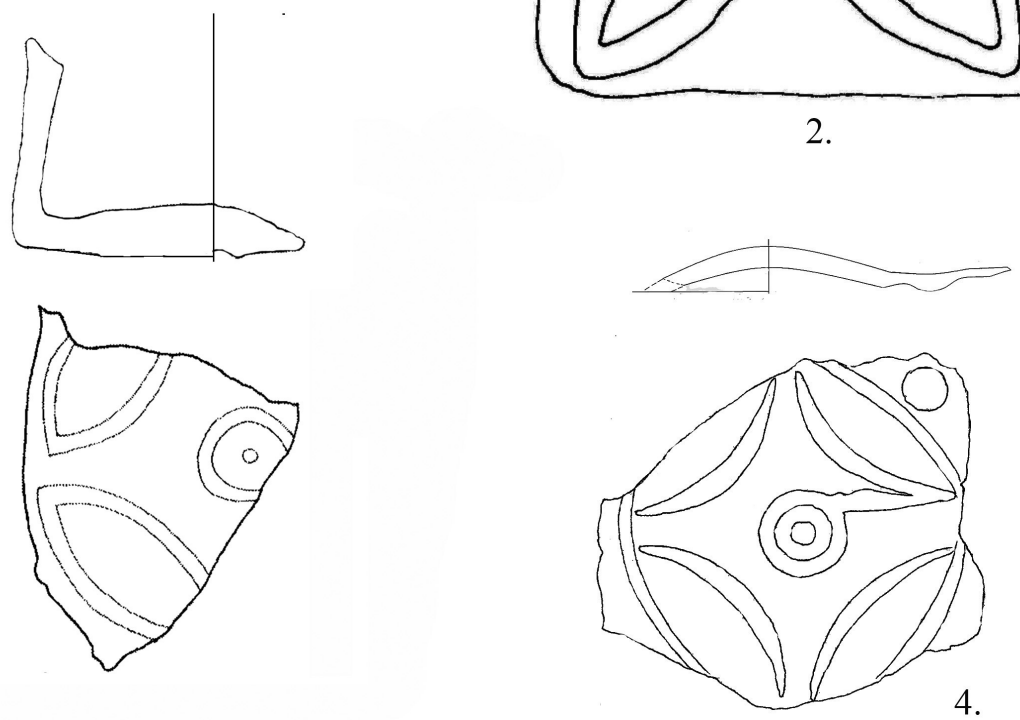

3.

$$
\text { 。 }
$$

T. II 1-2, 4. Локалитет Пећине, 3. Локалитет Чаир Pl. II 1-2, 4. The site of Pećine, 3. The site of Čair 